\section{Temporal and Spatial Distribution of Tomato Bacterial Wilt on Virginia's Eastern Shore}

\author{
Adam F. Wimer ${ }^{1}$, Steven L. Rideout ${ }^{1,3}$, and Joshua H. Freeman ${ }^{2}$
}

ADDITIONAL INDEX WORDS. Ralstonia solanacearum, ordinary runs analysis, Solanum lycopersicum

SUMMARY. Bacterial wilt of tomato caused by Ralstonia solanacearum is one of the most devastating diseases of tomato (Solanum lycopersicum) on the Eastern Shore of Virginia (ESV). Four research trials were conducted on the ESV over three growing seasons to determine the temporal and spatial distribution of bacterial wilt throughout commercial tomato fields. Individual plants were assessed at $\approx 1$-week intervals throughout the growing seasons with the incidence of bacterial wilt for each individual plant being recorded. Bacterial wilt increased gradually during each growing season. An increase in the clustered distribution of symptomatic plants was determined to exist within rows but not across rows. There were positive correlations between disease incidence and the percentage of rows exhibiting a significantly clustered distribution in every trial. These findings suggest that as bacterial wilt incidence increases in tomato fields by either the intimate contact between roots of adjacent tomato plants or the movement of the pathogen in surface irrigation water, symptomatic plants become more clustered within rows.

A bout 4500 acres of fresh market tomato are grown annually on the ESV (U.S. Department of Agriculture, 2009). Bacterial wilt, caused by Ralstonia solanacearum, is an economically important disease of tomato grown on the ESV and throughout the southeastern United States. Annual losses incurred by growers have not been published, but in certain fields, yield reductions of $50 \%$ have been observed. Traditionally, crop rotations with non-susceptible crops have been the most effective control recommendation in areas where bacterial wilt is present (Yuan et al., 1992). However, ESV tomato producers lack the available farmland to rotate tomato crops for extended periods of time and maintain profitability.

$R$. solanacearum is a gram negative bacterium with one to four polar flagella; it is aerobic, catalase and oxidase positive, and converts nitrates to nitrites (McCarter, 1993). The pathogen can infect over 200 plant species such as tomato, potato (Solanum

We thank East Coast Brokers and Packers and Six L's Packing Company for allowing us to conduct this research in their tomato fields.

${ }^{1}$ Department of Plant Pathology, Physiology and Weed Science, Eastern Shore Agricultural Research and Extension Center, Virginia Polytechnic Institute and State University, 33446 Research Drive, Painter, VA 23420

${ }^{2}$ Department of Horticulture, Eastern Shore Agricultural Research and Extension Center, Virginia Polytechnic Institute and State University, 33446 Research Drive, Painter, VA 23420

${ }^{3}$ Corresponding author. E-mail: srideout@vt.edu. tuberosum), banana (Musa acuminata), tobacco (Nicotiana tabacum), and many weed species that are asymptomatic (Hayward, 1991). Disease symptoms on tomato appear as wilting of the new growth followed by wilting of the entire plant. Progression from initial symptoms to complete wilting generally occurs within 3-7 d. The pathogen can survive over a wide temperature range of 10 to $41^{\circ} \mathrm{C}$, with the optimum between 25 and $35{ }^{\circ} \mathrm{C}$ (Hayward, 1991; McCarter, 1993). Infection by this pathogen occurs through wounds or natural openings in the root tissue of the susceptible hosts (Hayward, 1991; Kelman, 1953; McCarter, 1993). Considerable research has been conducted on the pathogen's host range, disease cycle, and control; however, this disease remains a problem on tomato in Virginia and other tomato production areas in the southeast United States.

The temporal and spatial spread of bacterial wilt within commercial tomato fields over time has not been thoroughly investigated. In a study by Madden et al. (1982), ordinary runs analysis was used to analyze the distribution pattern of maize dwarf mosaic virus in sweet corn (Zea mays). Madden et al. (1982) noted that this method was useful in evaluating temporal and spatial disease spread. The distribution patterns observed within commercial fields can determine factors that affect the pattern and spread of disease. For example, aggregated incidence of bacterial wilt within the rows of a commercial field could indicate that irrigation is a factor contributing to the spread of the disease. Irrigation with drip or trickle tape may deliver a large volume of water to the root zone, increasing the soil moisture around the roots where the pathogen is present. A more random distribution would indicate that initial soilborne inoculum is the greatest contributing factor to epidemics, signifying that secondary spread is not a significant contributor to an epidemic. Understanding the distribution of bacterial wilt within commercial fields may lead to better management techniques and strategies that suppress developing epidemics. The objective of this research was to determine the temporal and spatial dynamics of bacterial wilt within commercial tomato fields on the ESV. Ordinary runs analysis was used to determine distribution patterns of bacterial wilt in multiple commercial tomato fields and growing seasons in Virginia.

\section{Materials and methods}

FIELD TRIAL PRODUCTION PRACTICES. During 2006-2008, four commercial tomato fields were systematically evaluated to document the temporal and spatial distribution of tomato bacterial wilt in fields naturally infested with $R$. solanacearum. All trials were conducted in fields containing Bojac sandy loam soils (coarseloamy, mixed, semiactive, thermic Typic Hapludults). Standard fertilization and pest management practices for plasticulture production of fresh market tomato in Virginia were followed

\begin{tabular}{llll}
\hline $\begin{array}{l}\text { Units } \\
\text { To convert U.S. to SI, } \\
\text { multiply by }\end{array}$ & U.S. unit & SI unit & $\begin{array}{l}\text { To convert SI to U.S., } \\
\text { multiply by }\end{array}$ \\
\hline 0.4047 & acre $(\mathrm{s})$ & $\mathrm{ha}$ & 2.4711 \\
0.3048 & $\mathrm{ft}$ & $\mathrm{m}$ & 3.2808 \\
2.54 & inch $(\mathrm{es})$ & $\mathrm{cm}$ & 0.3937 \\
1.1209 & $\mathrm{lb} / \mathrm{acre}$ & $\mathrm{kg} \cdot \mathrm{ha}^{-1}$ & 0.8922 \\
$\left({ }^{\circ} \mathrm{F}-32\right) \div 1.8$ & ${ }^{\circ} \mathrm{F}$ & ${ }^{\circ} \mathrm{C}$ & $\left(1.8 \times{ }^{\circ} \mathrm{C}\right)+32$
\end{tabular}


(Kuhar et al., 2008). At Painter, VA, in 2006 , beds were fumigated with a mixture of methyl bromide and chloropicrin $[98 \% / 2 \%$ (by weight)] at a rate of $150 \mathrm{lb} /$ acre. In the 2007 and 2008 trials, beds were fumigated with a mixture of methyl bromide and chloropicrin $[67 \% / 33 \%$ (by weight)] at a rate of $150 \mathrm{lb} /$ acre. Beds were spaced $6 \mathrm{ft}$ from row middle to row middle, and plants were spaced $2 \mathrm{ft}$ in-row. Beds were 10 -inch tall and 2 -ft wide. Black polyethylene mulch was placed over raised beds with drip tape irrigation within the beds in all trials conducted in Painter, VA, in 2006, 2007, and 2008. Metalized mulch was placed over raised beds with drip tape irrigation within the beds in the 2007 trial conducted in Machipongo, VA. Transplanting in all trials occurred between 16 and 28 April in each year. 'BHN602' tomato (BHN Seed, Immokalee, FL) was used in all trials. The plants were staked and tied throughout the growing season using the string-weave method (Kuhar et al., 2008).

BaCterial Wilt inCIDENCE ASSESSMENTS. For each trial, four replicates were established, each consisting of 20 adjacent rows with 100 plants per row. The number and position of plants in each row exhibiting symptoms of bacterial wilt infection were recorded every 7-10 d. In 2006, the trial was established in Painter, VA, with initial observations on 14 July continuing until 14 Aug. (four assessments). Two locations were established in 2007, the same field near Painter, VA, as the 2006 trial and a field near Machipongo, VA. The fields in Painter, VA and Machipongo, VA were observed from 14 June to 1 Aug. (eight assessments) and from 21 June to 25 July (six assessments), respectively. A single trial was conducted near Painter, $\mathrm{VA}$, in 2008 in a different field than that assessed in 2006 and 2007. Observations began on 20 June and ended on 5 Aug. (seven assessments). Trials were concluded when producers finished harvesting the each field.

Data Analysis. Disease observations from all trials were analyzed using ordinary runs analysis by year (Gibbons, 1971). Individual disease assessments were entered into grid sheets in Excel (2003; Microsoft, Redmond, WA). Data were analyzed both within rows and across rows to determine if there were significant patterns of clustering. Rows exhibiting a clustered distribution were divided by the total number of rows in that particular repetition and assessment date to determine the percentage of rows showing a clustered distribution. Clustering was described in three equations as follows (Madden et al., 1982):

$$
E(U)=1+2 m(N-m) / N,
$$

where $m$ is equal to the number of infected plants in a row and $N$ is equal to the total number of plants. The total number of runs is represented by $U$. A run consists of two or more adjacent plants that are infected, surrounded by plants that are not infected and vice versa. The observed number of runs will be less than $E(U)$ (the expected number of runs), if there is clustering of infected plants. The standard deviation of $U$ is determined as follows:

$$
\begin{aligned}
& s_{u}=\{2 m(N-m)[2 m(N-m)-N] / \\
& \left.\left[N^{2}(N-1)\right]\right\}^{1 / 2}, \\
& Z_{\mathrm{u}}=[U+0.5-E(U)] /{ }^{S} u .
\end{aligned}
$$

The final equation calculates a standardized $U$ and corrects for continuity. Because the sampling distribution of $Z_{u}$ is assumed to be a standard normal distribution, and if the resulting value is a large negative number $\left(Z_{u}<-1.64\right)$, the distribution is considered to be clustered.

Agricultural Research Manager [ARM (version 7; Gylling Data Management, Brookings, SD)] was used to determine if a positive correlation existed between bacterial wilt disease incidence and the percentage of rows showing a clustered distribution. In addition, ARM was used to conduct analyses of variance (ANOVA) to determine if there were significant differences between the assessment dates within each trial for disease incidence and the percentage of rows showing a clustered distribution of disease. Means were compared using Fisher's least significant difference, with $P \leq 0.05$ indicating significance.

\section{Results}

2006 Painter, VA, trial. As the season progressed, the percentage of rows exhibiting a clustered distribution of diseased plants increased
(Table 1 ). At the conclusion of this trial, over $90 \%$ of the rows within each replication displayed a significant clustered pattern of wilted plants within rows. There was a positive correlation between disease incidence and rows showing a clustered distribution (Table 2). ANOVA for disease incidence across assessment dates indicated a significant increase in disease overall four observational dates (Table 1 ). The percentage of rows with a clustered distribution increased significantly from the first assessment date (14 July) to the latter assessment dates (26 July, 3 Aug., and 14 Aug.); however, the latter three dates were not significantly different from one another.

2007 Painter, VA, Trial. Similar to observations in 2006 , the percentage of rows exhibiting a clustered distribution increased as the 2007 season progressed. In this trial, $98.7 \%$ of the rows showed significant clustering of diseased plants within rows by the end of the trial (1 Aug.) (Table 1). A positive correlation between disease incidence and the percentage of clustered rows existed for the 2007 trial in Painter, VA (Table 2). Similar differences were detected in the percentage of rows exhibiting a clustered distribution of diseased plants, with most of the dates being significantly different from one another. As the season progressed, significant increases in disease incidence were observed for the five assessment dates from 3 July to 1 Aug. (Table 1).

2007 Machipongo, VA, trial. Similar results were observed in the Machipongo, VA, trial (Table 1 ) as noted in the 2006 and 2007 Painter, VA, trials. As the season progressed, the percentage of clustered rows increased. By midseason (11 July), 95\% of the rows exhibited a clustered distribution. The epidemic in the Machipongo, VA field was severe in 2007 , and many of the rows in this trial had $100 \%$ disease incidence by the end of the season. Once disease incidence within a row reaches $100 \%$, the distribution is no longer considered significantly clustered, causing a decrease in the percentage of clustered rows in the last two observations. ANOVA indicated significant differences in disease incidence and the percentage of rows showing a clustered distribution among the assessment dates until the last three dates, 11,18 , and 25 July (Table 1). Results from the correlation 
Table 1. The mean percentage of tomato bacterial wilt incidence and the percentage of rows exhibiting a clustered distribution of wilted plants for four trials conducted on the Eastern Shore of Virginia in 2006, 2007, and 2008.

\begin{tabular}{|c|c|c|}
\hline Date and location & Disease incidence (\%) & Clustered rows (\%) \\
\hline \multicolumn{3}{|l|}{2006 - Painter, VA } \\
\hline 14 July & $10.1 \mathrm{~d}^{\mathrm{z}}$ & $50.0 \mathrm{~b}$ \\
\hline 26 July & $26.2 \mathrm{c}$ & $82.5 \mathrm{a}$ \\
\hline 3 Aug. & $40.3 \mathrm{~b}$ & $90.0 \mathrm{a}$ \\
\hline 14 Aug. & $64.6 \mathrm{a}$ & $96.3 \mathrm{a}$ \\
\hline \multicolumn{3}{|l|}{2007 - Painter, VA } \\
\hline 14 June & $0.9 \mathrm{~g}$ & $3.8 \mathrm{e}$ \\
\hline 21 June & $2.1 \mathrm{fg}$ & $7.5 \mathrm{e}$ \\
\hline 27 June & $5.8 \mathrm{ef}$ & $32.5 \mathrm{~d}$ \\
\hline 3 July & $8.7 \mathrm{e}$ & $47.5 \mathrm{c}$ \\
\hline 11 July & $16.3 \mathrm{~d}$ & $71.3 \mathrm{~b}$ \\
\hline 19 July & $26.9 \mathrm{c}$ & $87.5 \mathrm{a}$ \\
\hline 26 July & $35.8 \mathrm{~b}$ & $96.3 \mathrm{a}$ \\
\hline 1 Aug. & 42.1 a & 98.8 a \\
\hline \multicolumn{3}{|c|}{2007 - Machipongo, VA } \\
\hline 21 June & $15.2 \mathrm{e}$ & $53.8 \mathrm{c}$ \\
\hline 28 June & $32.1 \mathrm{de}$ & $69.5 \mathrm{~b}$ \\
\hline 2 July & $39.3 \mathrm{~cd}$ & $81.5 \mathrm{ab}$ \\
\hline 11 July & $55.3 \mathrm{c}$ & $95.3 \mathrm{a}$ \\
\hline 18 July & $70.6 \mathrm{ab}$ & $92.3 \mathrm{a}$ \\
\hline 25 July & $76.2 \mathrm{a}$ & $86.3 \mathrm{a}$ \\
\hline \multicolumn{3}{|l|}{2008 - Painter, VA } \\
\hline 20 June & $5.7 \mathrm{f}$ & $30.0 \mathrm{~d}$ \\
\hline 26 June & $17.7 \mathrm{e}$ & $48.8 \mathrm{c}$ \\
\hline 3 July & $44.3 \mathrm{~d}$ & $86.3 \mathrm{~b}$ \\
\hline 11 July & $62.3 c$ & $93.8 \mathrm{ab}$ \\
\hline 18 July & $70.3 \mathrm{bc}$ & $100.0 \mathrm{a}$ \\
\hline 24 July & $75.9 \mathrm{~b}$ & 98.8 a \\
\hline 5 Aug. & $88.0 \mathrm{a}$ & $98.8 \mathrm{a}$ \\
\hline
\end{tabular}

${ }^{2}$ Values followed by the same letter indicate no significant differences $(P \leq 0.05)$ within each trial and within each column according to Fisher's least significant difference mean comparisons.

Table 2. Correlation between tomato bacterial wilt incidence and the percentage of rows that had a clustered distribution of tomato bacterial wilt for four trials conducted in Eastern Shore of Virginia commercial tomato fields from 2006 to 2008 . Twenty-five assessment dates were used for analysis over 3 years.

\begin{tabular}{lccc}
\hline Yr - location & $R^{2 \mathrm{z}}$ & $R^{\mathrm{y}}$ & $P>r$ \\
\hline 2006 - Painter, VA & 0.48 & 0.69 & 0.0029 \\
2007 - Painter, VA & 0.85 & 0.92 & 0.0001 \\
2007 - Machipongo, & 0.60 & 0.77 & 0.0001 \\
VA & & & \\
2008 - Painter, VA & 0.83 & 0.91 & 0.0001
\end{tabular}

${ }^{\mathrm{z}}$ Coefficient of determination.

yCorrelation coefficient.

analysis between disease incidence and the percentage of rows depicting a clustered distribution revealed a positive correlation (Table 2 ).
2008 Painter, VA, trial. Similar results occurred in the 2008 trial as observed in previous trials (Table 1 ). The percentage of rows exhibiting a clustered distribution increased as the season progressed. The percentage of rows showing a significantly clustered distribution of diseased plants within rows was at least $95 \%$ by 18 July. Most of the assessment dates had a significantly higher disease incidence than that in the previous assessment date (Table 1). In this trial, there was no significant increase in the percentage of clustered rows after the third assessment date (3 July). There was a positive correlation between disease incidence and the percentage of clustered rows (Table 2).

\section{Discussion}

These results indicate that disease pressure increases throughout the growing season. The use of ordinary runs analysis determined that tomato bacterial wilt became more clustered within rows as the growing season progressed. Results from the correlation analysis for all four trials indicated a strong positive correlation between disease incidence and the percentage of rows showing a clustered distribution of disease.

The results from these trials indicated that a common factor (or factors) contributes to a clustered distribution within rows. Analysis of the data across rows using ordinary runs did not show a high percentage $(<20 \%)$ of clustering (data not presented), further indicating spread within rows is more important than across rows in the development of bacterial wilt epidemics. The constant increase in disease incidence and rows with a clustered distribution within rows indicates that secondary spread between adjacent plants is occurring. One of the major differences between within rows and across rows is the plant-to-plant proximity. Plant spacing was $\approx 2 \mathrm{ft}$ within rows, whereas across the rows the plant spacing was $\approx 6 \mathrm{ft}$.

Two possible factors that could explain the significantly clustered distribution pattern within rows that were observed in these trials are that $R$. solanacearum is spread in irrigation water and/or that disease is spread from bacterial root exudates. Research conducted in Brazil reported drip irrigation at varying frequencies significantly increased bacterial wilt incidence in tomato, when compared with overhead irrigation (Marouelli et al., 2005). By applying irrigation water directly to the root zone and maintaining high soil moisture in this area, drip irrigation creates an optimal environment to promote clustered distribution of diseased plants within rows. Previous research in other geographical areas has shown $R$. solanacearum can reside in irrigation ponds. Elphinstone et al. (1997) indicated that two outbreaks of potato bacterial wilt ( $R$. solanacearum) were associated with contaminated irrigation water. Researchers also reported that the pathogen was in higher concentration in the irrigation water when samples were taken downstream of the susceptible weed host bittersweet nightshade (Solanum dulcomara). Research conducted in Florida indicated 
similar findings. Hong et al. (2005) determined that $R$. solanacearum was present in north Florida irrigation ponds during the months of May to October. Hong et al. (2005) also reported the pathogen was associated with dominant weed species that grew around these irrigation ponds, such as Pennsylvania smartweed ( $\mathrm{Po}_{0}$ lygonum pennsylvanicum) and water pennywort (Hydrocotyle ranunculoides). Irrigation sources on the ESV are mostly surface water ponds, which have been implicated as possible sources of inoculum. Irrigation water contaminated with $R$. solanacearum could exacerbate disease incidence by dispersing $R$. solanacearum into the root zone of susceptible tomato plants.

Further research should be conducted to examine if increased plant spacing, limiting the root-to-root contact of neighboring plants, or possible irrigation alternatives other than surface water ponds could suppress this disease without reducing yields. Gallegly and Walker (1949) showed that periodic dry conditions arrested disease development and slowed the spread of tomato bacterial wilt. Reducing the frequency of irrigation is one possible alternative to the irrigation regimes currently in use. Commercial growers on the ESV generally irrigate twice daily especially as tomato plants get larger and as temperatures increase. Reduced frequency of irrigation could create dry periods within the beds that may reduce disease incidence or slow the spread of the pathogen within a field. However, reducing the frequency of irrigation at the cost of plant health would not be an acceptable alternative to the current tomato production practices.

\section{Literature cited}

Elphinstone, J.G., H.M. Stanford, and D.E. Stead. 1997. Detection of Ralstonia solanacearum in potato tubers, Solanum dulcamara and associated irrigation water, p. 133-139. In: P. Prior, C. Allen, and J. Elphinstone (eds.). Bacterial wilt disease: Molecular and ecological aspects. Springer-Verlag, Berlin, Heidelberg, New York.

Gallegly, M.E. and J.C. Walker. 1949. Relation of environmental factors to bacterial wilt of tomato. Phytopathology 39: 936-946.

Gibbons, J.D. 1971. Nonparametric methods for quantitative analysis. Holt, Rinehart, Winston, New York.

Hayward, A.C. 1991. Biology and epidemiology of bacterial wilt caused by Pseudomonas solanacearum. Annu. Rev. Phytopathol. 29:65-87.

Hong, J., P. Ji, M.T. Momol, J.B. Jones, S.M. Olson, P. Pradhanang, and K.
Guven. 2005. Ralstonia solanacearum detection in tomato irrigation ponds and weeds. Acta Hort. 695:309-311.

Kelman, A. 1953. The bacterial wilt caused by Psendomonas solanacearum. North Carolina Agr. Expt. Sta. Bul. 99: 194.

Kuhar, T.P., C. Waldenmaier, H.B. Doughty, S. Rideout, J.H. Freeman, M. Reiter, R.A. Straw, H.P. Wilson, and T.E. Hines. 2008. Commercial vegetable production recommendations. Virginia Coop. Ext. Publ. 456-420.

Madden, L.V., R. Louie, J.J. Abt, and J.K. Knoke. 1982. Evaluation of tests for randomness of infected plants. Phytopathology 72:195-198.

Marouelli, W.A., C.A. Lopes, and W.L.C. Silva. 2005. Incidence of bacterial wilt on processing tomato under drip and sprinkle irrigation. Horticultura Brasileira 23:320 333.

McCarter, S.M. 1993. Bacterial wilt, p. 28-29. In: J.B. Jones, J.P. Jones, R.E. Stall and T.A. Zitter (eds.). Compendium of tomato diseases. American Phytopathological Society, St. Paul, MN.

U.S. Department of Agriculture. 2009. Agricultural statistics for 2009. 11 Dec. 2009. <http://www.nass.usda.gov/ Data_and_Statistics/index.asp $>$.

Yuan, L.H., Q.L. Su, and Y.H. Yi. 1992. A brief report on the technique for control of tomato bacterial wilt disease. Plant Protection 18:48-49. 